\title{
高速液体クロマトグラフィーによる豚肉中のデストマイシン $\mathrm{A}$ ，ハイグロマイシン B の定量
}

(昭和 62 年 7 月 2 日受理)

$$
\text { 中屋謙一* 杉谷哲* 河 合 信* }
$$

\section{Determination of Destomycin A and Hygromycin B in Pork by High Performance Liquid Chromatography}

\author{
Ken-ichi Nakaya, Akira Sugitani and Makoto KawaI \\ (Gifu Prefectural Institute of Public Health: 4-6-3, Noishiki, Gifu, Japan)
}

\begin{abstract}
A sensitive and simple method for simultaneous determination of destomycin A (DM) and hygromycin B (HM) in pork by high performance liquid chromatography with a fluorescense detector was developed.

$\mathrm{DM}$ and $\mathrm{HM}$ was extracted with $10 \%$ trichloroacetic acid, and the extract was applied to an Amberlite CG-50 column ( $\mathrm{NH}_{4}$ form) followed by a Dowex $1 . \mathrm{X} 8$ column (OH form) to obtain a test solution. A portion of the test solution was treated with $o$-phthalaldehyde to derivatize DM and HM. The derivatives were separated on a TSK gel ODS:120T column with methyl alcohol-water-acetonitrile $(65: 30: 5)$ as the mobile phase and quantitated by fluorometry.

Recoveries of DM and HM added to pork at levels of 0.25 and $0.5 \mu \mathrm{g} / \mathrm{g}$ and at 0.5 and 1.0 unit/g were 73.8 and $82.5 \%$, and 77.4 and $81.6 \%$, respectively. The detection limits were $0.1 \mu \mathrm{g} / \mathrm{g}$ for $\mathrm{DM}$ and $0.3 \mathrm{unit} / \mathrm{g}$ for $\mathrm{HM}$ in the sample.
\end{abstract}

(Received July 2, 1987)

Key words: デストマイシン A destomycin A; ハイグロマイシン B hygromycin B; 豚肉 pork; 高速液体クロマトグラフィー high performance liquid chromatography; 0 -フタルアルデヒ ド $o$-phthalaldehyde; 蛍光検出器 fluorescence detector

\section{はじめに}

飼料添加物は, 飼料が含有している栄養成分の有効な 利用の促進を目的としているが，このうち抗生物質は疾 病の予防, 発育促進剤, 抗コクシジウム剂, 寄生虫駆除 剂としての用途 ${ }^{1)}$ が考えられ現在使用が認められている ものは19種類である. このうちアミノグリュシド系抗生 物質では, デストマイシン A (DM), ハイグロマイシン $\mathrm{B}(\mathrm{HM})$ の 2 種類のみがブタ, ニワトリの寄生虫駆除の 目的で使用され需要も多い2). また両者の併用は禁止さ れている.

$\mathrm{DM}, \mathrm{HM}$ を含めアミノグリコシド系抗生物質の食品 中残留検査は, 従来一般的に微生物学的方法 ${ }^{32,4)}$ により 行われているが, 特異性, 定量性の点で必ずしも優れた

* 岐阜県衛生研究所：岐阜県岐阜市野一色 4-6-3
方法とは言い難い。このため最近ではガスクロマトグラ フィー5), 高速液体クロマトグラフィー6),7) (HPLC) あるいは蛍光基質免疫測定法 ${ }^{8)}$ などの化学的分析法が開 発されて来ている：著者らは前報 (で残留カナマイシン の HPLC による定量法を報告したが，今回この方法に 若干の改良を加え, DM と HM を同時に定量する方法 について検討し良好な結果が得られたので報告する.

\section{材料及び方法}

1. 試料

岐阜県内で購入した抗生物質残留の認められないブタ の筋肉部を用いた.

\section{2. 試薬}

常用標準デストマイシン A (DM): 農林水産省東京肥 飼料検查所配布品, $997 \mu \mathrm{g}$ 力価 $/ \mathrm{mg}$

常用標準ハイグロマイシン B (HM)：武田薬品工業 
(株) 製, 1137 unit/mg

DM, HM 標準溶液：DM 及び HM を精秤し水に溶 解し, 各 $100 \mu \mathrm{g}$ 力価 $/ \mathrm{ml}, 100 \mathrm{unit} / \mathrm{ml}$ の混合標準原液 を調製し $4^{\circ}$ 以下に保存した。使用の都度標準原液を $0.05 M$ 水酸化カリウムで所要濃度に希釈して用いた.

○-フタルアルデヒド試薬：前報6) に準じて調製した.

CG-50 樹脂カラム：前報6) 飞準じて調製した.

Dowex 1-X8 樹脂カラム: Dowex 1-X8 樹脂を水洗 後, 各 $2 N$ 濃度のアンモニア水, 硫酸アンモニウム, 塩 酸, 硫酸アンモニウム, 水酸化ナトリウムで順次処理し, 最後に中性になるまで水洗した後， $10 \times 300 \mathrm{~mm}$ のガラ スカラムに $5 \mathrm{~cm}$ 高になるよう充てんして用いた。

その他の試薬はいずれも市販特級品を用いた.

3. 装

ホモジナイザー, 高速液体クロマトグラフ, 蛍光検出 器：前報6) 飞同じ

データ処理装置：(株)島津製作所製 C-R3A Chromatopac

\section{4. 試験溶液の調製}

前報6) 飞準じ細切試料 $10 \mathrm{~g}$ に $10 \%$ トリクロロ酰酸 $20 \mathrm{ml}$ を加え, 抽出及び除タンパクを行う.上澄液をエ 一テル洗浄後, $1 N$ 水酸化ナトリウムで $\mathrm{pH} 7.5$ に調整 し, CG-50 カラムに通し, 水 $100 \mathrm{ml}$ で洗浄後 $1 N$ アン モニア水で溶出する．得られた溶出液を Dowex 1-X8 カラムに通し素通り画分を捕集し，さらに水 $10 \mathrm{ml}$ で カラムを洗浄し洗液を得る。この両液を合せて濃縮乾固 し, $0.05 M$ 水酸化カリウム $1 \mathrm{ml}$ 飞溶解し試験溶液とし た.

\section{5. 誘 導 体化}

試験溶液 $0.5 \mathrm{ml}$ を $10 \mathrm{ml}$ 共栓試験管にとり, 以下前 報6) に準じ 0 -フタルアルデヒド試薬 $0.5 \mathrm{ml}$ を加党密栓 後速か飞 20 秒間攪汼混合する. $30^{\circ}, 10$ 分間誘導体化反 応を行い, 更に $50^{\circ}, 5$ 分間反応を継続する. 反応終了後 HPLC に供するまで氷冷しておいた。

\section{6. 定}

5. の方法により得られた 0 -フタルアルデヒド誘導体 飞移動相 $4 \mathrm{ml}$ を加光, Table 1 の条件で HPLC 飞供 した。な抢定量は面積による絶対検量線法で行った。

\section{7. 検量線の作製}

DM $1.0 \sim 20 \mu \mathrm{g} / \mathrm{ml}, \mathrm{HM} 3.0 \sim 40 \mathrm{unit} / \mathrm{ml}$ となるよう 標準混合溶液を調製し, 各 $0.5 \mathrm{ml}$ を. 及び $\mathbf{6}$. の方法
により操作し検量線を作製した。

\section{結果及び考察}

1. 前処理方法の検討

1) 抽出溶媒

DM, HM の抽出には前報6) と同様 $10 \%$ トリクロロ 酢酸を用いたが，クロマトグラム上定量の妨害となる物 質は認められなかった。

2) CG-50 カラムからの溶出挙動

DM $10 \mu \mathrm{g}$, HM 20 unit をカラムに吸着し, $1 N$ アン モニア水による溶出挙動について検討した. DM, HM とも $10 \sim 30 \mathrm{ml}$ の溶出画分に $97.3 \% ， 96.1 \%$ 回収され たが確実性を考慮して $50 \mathrm{ml}$ で溶出し, 全量を捕集す ることにした (Fig. 1).

3） Dowex 1-X8 カラムによる妨害物質の除去 試料抽出液の CG-50 カラムからの溶出物には, 極性 の高い物質と思われるピークがクロマトグラム先端に現 われ DM の検出に影響を及ぼす。そこで陰イオン交換 樹脂である Dowex 1-X8 (OH 型) カラムを通したとこ ろこれらのピークは除かれクリーンアップ効果が認めら れた。 また DM, HM の吸着による損失は認められなか った.

\section{2. 誘導体化条件の検討}

1）反応条件

前報6) と同一条件で DM 及び HM の誘導体生成量に ついて検討した. Fig. 2，Fig. 3 飞示すように DM, $\mathrm{HM}$ とも同様な傾向を示し，また前報6) の結果ともほぼ

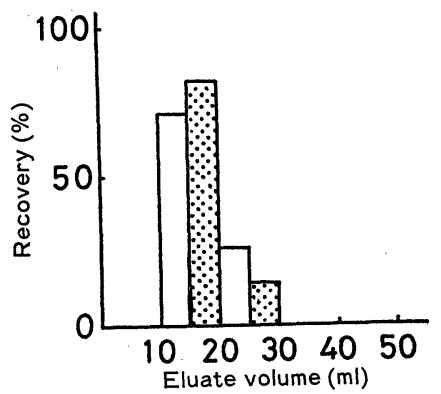

Fig. 1. Elution pattern of destomycin $\mathrm{A}$ and hygromycin B from CG-50 column (70 $\mathrm{mm} \times 15 \mathrm{~mm}$ i.d.) with $1 \mathrm{~N} \mathrm{NH}_{4} \mathrm{OH}$

$\square$ : destomycin A

$\because \because \cdot$ : hygromycin $\mathrm{B}$

Table 1. Operating Condition of HPLC

\begin{tabular}{ll}
\hline \hline Instrument & Japan Spectroscopic TRIROTAR-V \\
Column & TSK gel ODS-120T $250 \mathrm{~mm} \times 4 \mathrm{~mm}$ i.d. \\
Mobile phase & $\mathrm{CH}_{3} \mathrm{OH}-\mathrm{H}_{2} \mathrm{O}-\mathrm{CH}_{3} \mathrm{CN}(65: 30: 5)$ \\
Flow rate & $0.8 \mathrm{ml} / \mathrm{min}$ \\
Detector & Japan Spectroscopic Spectrofluorometer FP.210 (Ex. $335 \mathrm{~nm}$, EM. $440 \mathrm{~nm})$ \\
Sample size & $5 \mu 1$ \\
\hline
\end{tabular}




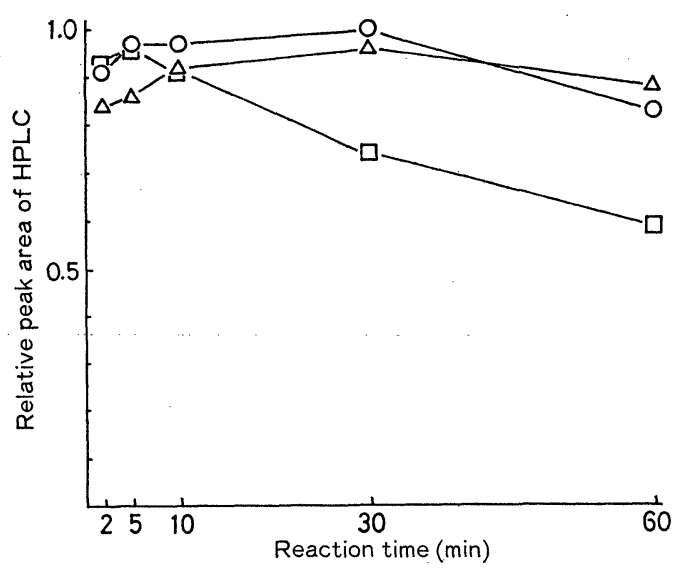

Fig. 2. Effect of reaction time and temperature on $o$-phthalaldehyde derivatization of destomycin $\mathrm{A}$ $\longrightarrow \triangle-: 30^{\circ} \mathrm{C} ;-\square-: 50^{\circ} \mathrm{C} ;-0-: 30^{\circ} \mathrm{C} \rightarrow$ $50^{\circ} \mathrm{C}$ (heated at $30^{\circ} \mathrm{C}$ for timed intervals and at $50^{\circ} \mathrm{C}$ for $5 \mathrm{~min}$ )

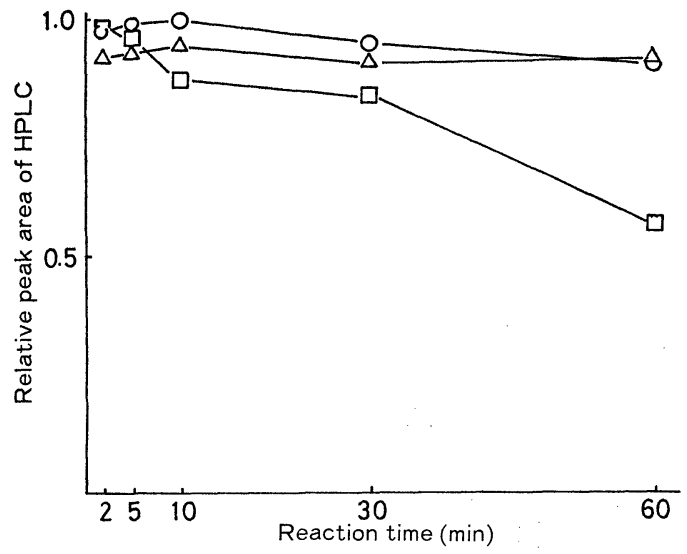

Fig. 3. Effect of reaction time and temperature on $o$-phthalaldehyde derivatization of hygromycin $\mathrm{B}$

- $\triangle$ : $30^{\circ} \mathrm{C}$; - $\square-: 50^{\circ} \mathrm{C} ;-\mathrm{O}-: 30^{\circ} \mathrm{C} \rightarrow$ $50^{\circ} \mathrm{C}$ (see Fig. 2)

同一であった．このため反応条件は $30^{\circ}, 10$ 分反応後更 に $50^{\circ}, 5$ 分反応を継続することにした。

2) 誘導体の安定性

生成した誘導体を氷冷状態に保った場合と, 室温に放 置した場合の安定性を比較し, Fig. 4 亿示した. 水冷状 態では DM, HM とも 120 分までほとんど变化が見ら れなかったが，室温放置した場合は DM で 70\%，HM で 65\% 飞低下した。 このため反応終了後 HPLC に供 するまで氷冷して拈くことにした。

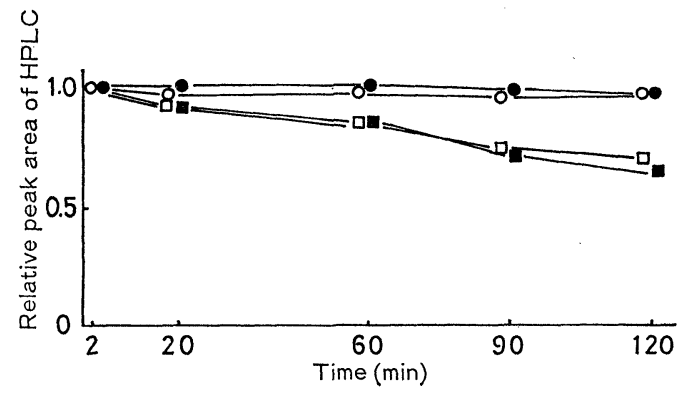

Fig. 4. Stability of $o$-phthalaldehyde derivative of destomycin $\mathrm{A}$ and hygromycin $\mathrm{B}$ -O-: destomycin A in ice bath;

--: hygromycin B in ice bath;

- $\square-$ : destomycin $A$ at room temp.;

-n-: hygromycin B at room temp.

\section{HPLC 測定条件の検討}

1) カラム及び移動相の組成

TSK gel ODS 120T, Nucleosil $\mathrm{C}_{18}$ の両充てん剤に ついて，また移動相はメタノールー水ーアセトニトリル $(65: 30: 5)^{6)}$ を用い DM と HM の分離を検討した. いず れの充てん剂でも分離は可能であったが, Nucleosil $\mathrm{C}_{18}$ では比較的吸着が強く分析時間が長くなる傾向が見られ たこと，カラム圧が高くなることなどの理由により TSK gel ODS 120T を使用することにした。 またカラ 厶長は DM，HM 相互の分離を良くするため $250 \mathrm{~mm}$ とした。更に TSK gel ODS $120 \mathrm{~T}$ を用いリン酸緩衝 液ーメタノール系での分離を検討した。標準溶液では 10 $\mathrm{m} M$ リン酸緩衝液 $(\mathrm{pH} 7.0)$-メタノール $(52: 48)$ で分離 可能であったが, 試験溶液では夾雑ピークが多数出現し 実用的ではなかった。

\section{2) 測定波長}

DM, HM 誘導体の蛍光スペクトルを測定したところ 前報6) と同様最大励起波長 $335 \mathrm{~nm}$, 最大蛍光波長 440 $\mathrm{nm}$ を示したため本条件を採用した。

\section{3) 妨害物質}

試料からの妨害物質は認められなかった．また本法に 括いて他のアミノ:グリコシド系抗生物質 (カナマイシン, フラジオマイシン, カスガマイシン, ストレプトマイシ ン，ジヒドロストレプトマイシン) は定量の妨害とはな らなかった。

\section{4. 検量線の精度及び検出限界}

DM $0.5 \sim 10 \mathrm{ng} ; \mathrm{HM} \quad 1.5 \sim 20 \times 10^{-3}$ unit の範团で原 点を通る良好な直線性を示した. DM $5 \mathrm{ng}, \mathrm{HM} 20 \times 10^{-3}$ unit を用い繰返し測定した場合の変動係数は, 各々 $1.72 \%(n=5), 1.20 \%(n=5)$ であった。 また検出限界は DM $0.5 \mathrm{ng}, \mathrm{HM} 1.5 \times 10^{-3}$ unit であった.

\section{5. 添加回収実験}

市販の豚肉各 $10 \mathrm{~g}$ そ DM 2.5, $5 \mu \mathrm{g}, \mathrm{HM} 5,10$ unit 
Table 2. Recovery of Destomycin A and Hygromycin B from Pork

\begin{tabular}{|c|c|c|c|c|}
\hline & Added & $\begin{array}{l}\text { Found } \\
(\mu \mathrm{g})\end{array}$ & $\begin{array}{c}\text { Recovery } \\
(\%)\end{array}$ & $\underset{(\%)}{\operatorname{Mean} \pm \text { S.D. }}$ \\
\hline \multirow{10}{*}{ Destomycin A $(\mu \mathrm{g})$} & \multirow{5}{*}{2.5} & 1.89 & 75.4 & \multirow{5}{*}{$73.8 \pm 5.1$} \\
\hline & & 1.85 & 74.4 & \\
\hline & & 1.82 & 72.8 & \\
\hline & & 2.01 & 80.3 & \\
\hline & & 1.64 & 66.3 & \\
\hline & \multirow{5}{*}{5.0} & 4.33 & 86.6 & \multirow{5}{*}{$82.5 \pm 2.9$} \\
\hline & & 3.93 & 78.5 & \\
\hline & & 4.07 & 81.4 & \\
\hline & & 4.13 & 82.7 & \\
\hline & & 4.17 & 83.3 & \\
\hline \multirow{10}{*}{ Hygromycin B (unit) } & \multirow{5}{*}{5.0} & 3.67 & 73.3 & \multirow{5}{*}{$77.4 \pm 11.8$} \\
\hline & & 4.81 & 96.2 & \\
\hline & & 3.96 & 79.1 & \\
\hline & & 3.22 & 64.4 & \\
\hline & & 3.69 & 73.8 & \\
\hline & \multirow{5}{*}{10.0} & 8.36 & 83.6 & \multirow{5}{*}{$81.6 \pm 2.9$} \\
\hline & & 8.30 & 83.0 & \\
\hline & & 8.31 & 83.1 & \\
\hline & & 7.66 & 76.6 & \\
\hline & & 8.17 & 81.7 & \\
\hline
\end{tabular}

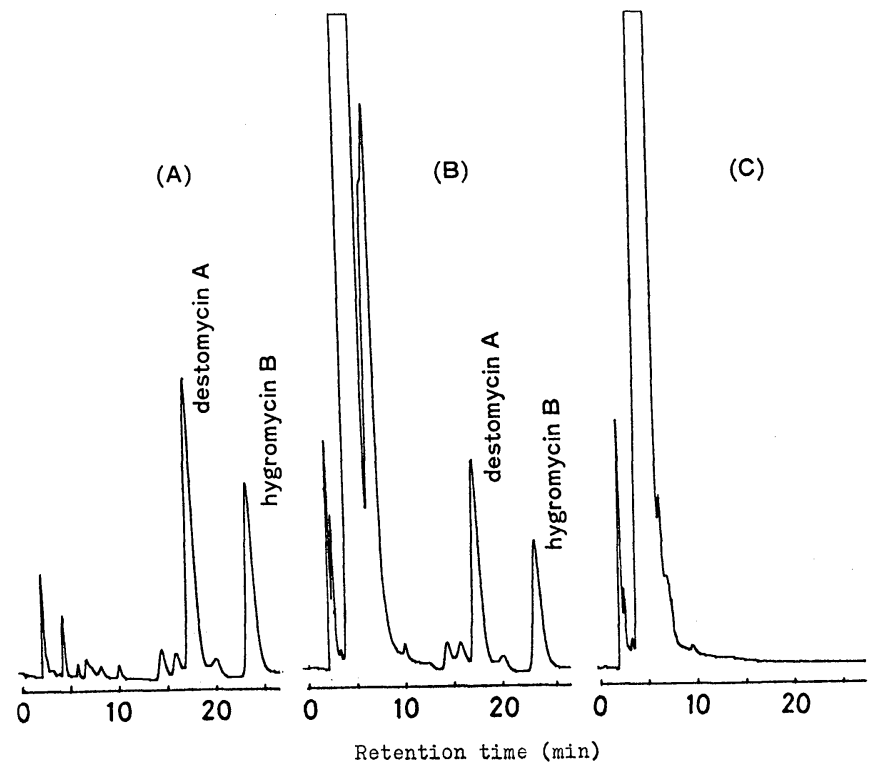

Fig. 5. High performance liquid chromatogram of standard (A), extracts from pork (B) and blank pork (C)

Destomycin A and hygromycin B were added $1 \mu \mathrm{g} / \mathrm{g}$ and 2 unit/g sample respectively. 
を添加し回収率を求めた。 Table 2 に示すように DM $73.8,82.5 \%$, HM 77.4, 81.6\% の平均回収率が得られ た.またそのクロマトグラムを Fig. 5 に示した.

市販の豚肉 5 検体について本法を適用した結果, いず れの検体からも DM, HM は検出されなかった.

\section{まとめ}

豚肉中の残留 $\mathrm{DM}, \mathrm{HM}$ を により蛍光誘導体とし，HPLC で同時に定量する方法 を検討し以下の結果を得た.

1) 試料からの DM, HM の抽出は，10\%トリクロ 口酢酸によった. 抽出液をェーテル洗浄後 $\mathrm{pH} 7.5$ に調 整し，CG-50 カラム次いで Dowex 1-X8 カラムにより 精製し, 一部を 0 -フタルアルデヒド試薬により蛍光誘導 体とし HPLC に供した. 検出は蛍光検出器（励起波長 $335 \mathrm{~nm}$ ，蛍光波長 $440 \mathrm{~nm}$ ) を用いた。

2) HPLC カラムは TSK gel ODS 120T, 移動相は メタノールー水ーアセトニトリル $(65: 30: 5)$ 混液とした。

3) 本法の豚肉での回収率は DM $0.25 \mu \mathrm{g} / \mathrm{g}, 0.5 \mu \mathrm{g} /$ $\mathrm{g}$ 添加で 73.8, 82.5\%, HM 0.5 unit/g, 1.0 unit/g 添加 で 77.4, 81.6\% であった. 定量限界は DM $0.1 \mu \mathrm{g} / \mathrm{g}$, HM 0.3 unit/g であった。
4) 市販の豚肉 5 検体に本法を適用した結果，いずれ の検体からも DM, HM は検出されなからた。

本報告の一部は第52回日本食品衛生学会学 術 講 演 会 (1986年11月, 高知) で発表した.

文献

1）（財）畜産生物化学研究所編：“動物用医薬品・飼 料添加物の畜・水産物への残留とその分析法” p. 1 24 (1985) 近代出版.

2）矢ケ崎忠夫：食衛誌. 27，451～465 (1986).

3）厚生省環境衛生局乳肉衛生課：“畜産物中の残留 物質検查法”第 1 集 p. 23～24 (1977).

4）厚生省環境衛生局乳肉衛生課：“畜水産食品中の 残留物質検查法”第 1 集の 3 p. 1 5 (1981).

5) 中屋謙一, 杉谷 哲, 山田不二造：食衛誌. 26, 443 447 (1985).

6) 中屋謙一, 杉谷 哲, 山田不二造：同上 27,258 $\sim 262$ (1986).

7) 米田 豊, 岡田紀子, 溝口省三, 床鍋嘉昭, 城石 将幸，吉本善次郎：同上 27, 369 374 (1986).

8) 堀江正一, 斉藤貢一, 星野庸二, 能勢憲英, 中沢 裕之, 藤田昌彦: 同上 27, 413 416 (1986). 